various types of phyllotaxis, and decided that a morphological theory of spiral growth must be based on a logarithmic spiral on a plane surface. This conclusion and the mathematical reasoning, it must be admitted, did not awake an enthusiastic response on the part of the average botanist.

In 1908 the Oxford University Press published a sumptuous folio volume "Types of Floral Mechanism" in which are described twelve early spring flowers with drawings, many in colour, which have never been surpassed in accuracy. A few years later, Church gave much pleasure to me by acting upon a suggestion that he should apply methods, previously used by him in the description and delineation of Angiosperm flowers, to the elucidation of the floral morphology of the remarkable African Gymnosperm Welwitschia mirabilis. The results were communicated to the Royal Society in 1914. A series of "Elementary Notes" on Angiosperms, Gymnosperms and Fungi (1919-21), printed as pamphlets, that are models of concise and logical presentation of facts and theories, bear testimony to his determination to raise the standard of teaching to the highest level. Three admirable botanical memoirs on "Plant Life of the Oxford District" have much more than a local value and should be more widely known.

The best known of Church's Oxford Memoirs is "Thalassiophyta and the Subaerial Transmigration" (1919). The opening words, "The beginnings of Botany are in the sea", served as a text for a learned and exceedingly interesting thesis on the origin of terrestrial vegetation. His view was that life began in a primeval ocean covering the surface of the earth ; free-swimming flagellates were succeeded by encysted organisms attached to the sea-floor, some of which in the course of ages developed into highly differentiated green algæ comparable in size and complexity to the large brown seaweeds of our rocky coasts. At a later stage, portions of the earth's crust were uplifted above the surface of the world-ocean, and some of the aquatic algæ that had reached an advanced state of differentiation were, he believed, able to grapple successfully with the serious problems presented by a changed environment and became the advanced guard of a land flora : "the origin of all the main successful adaptations of the land are to be traced down to the benthic phase of the sea". The Thalassiophyta memoir was preceded by one on "The Building of an Autotrophic Flagellate" (1919). $\mathrm{He}$ afterwards published several papers in the Journal of Botany (1924-25) and elsewhere in elaborating the main thesis.

Church's fascinating hypothesis, not perhaps wholly new, was presented by him in an original form and with a wealth of argument and fact: it has been vigorously criticized by botanists who envisage a different origin of land vegetation; but to many it makes a strong appeal as a contribution to speculative science which will endure.

Forgetting his idiosyncrasies and regrettable aloofness, we think of Church as a self-sacrificing, devoted, kind-hearted teacher, and as one of the ablest and most original botanists of our time.

A. C. Seward.
Diwan Bahadur L. K. Ananthakrishna Iyer

$\mathrm{WE}$ much regret to announce that Dr. Ananthakrishna Iyer, whose name is well known to all students of Indian sociology, died on February 25 at Palghat in the Malabar district of the Madras Presidency.

Born of a southern Indian Brahman family at Palghat in 1861, and educated at the local Government high-school, this well-known scholar graduated at the University of Madras and entered Government service, which he soon relinquished to join the staff of the Victoria College at Palghat. He then became an inspector of schools in the Cochin State, in which position his services were utilized to develop a State museum, zoological gardens and an industrial bureau. Thus he possessed suitable qualifications for taking part in the systematic ethnographical survey of India which was set on foot by the late Sir Herbert Risley as a sequel to the Census of 1901. Two volumes dealing with the tribes and castes of the Cochin State were issued by him in 1907 and 1912 respectively. The University of Calcutta then invited him to organize a Department of Anthropology, of which he became chairman in 1920 .

When in 1924 the superintendent of the Mysore Ethnographic Survey, Mr. H. B. Nanjundayya, unfortunately died, leaving the Survey only partly accomplished, the Mysore State selected Ananthakrishna Iyer to succeed him. Thus commenced the most important of the latter's numerous tasks, and one which will serve as a lasting memorial to his energy and powers of research. Between 1924 and 1935, four volumes were published, giving an account of the population of Mysore on the lines laid down for the Ethnographical Survey, and containing a mass of interesting materials skilfully marshalled by the editor. The first volume, published last, contains a summary of the contents of the other three, and is enriched by contributions from such scholars as Dr. R. R. Marrett, M. Sylvain Lévi, Baron Eickstedt and Mr. C. S. Richards. The public were promised a further volume containing some additional materials, but it is feared that this may not now be available. The loss would be regrettable as it was expected to remedy an obvious defect in the first four, namely, an omission of any list of tribal and caste synonyms, an indispensable guide for scholars who are not familiar with the many names under which Indian social divisions are frequently hidden.

While preparing his final effort, in relation to Mysore, Ananthakrishna Iyer attempted a survey of the small State of Coorg on parallel lines. It is understood that this work was well advanced at the time of his death. It is therefore earnestly hoped that the completion and publication will be entrusted to some competent scholar by the Coorg State.

As a foundation member of the Indian Science Congress, Ananthakrishna Iyer endeavoured to popularize the study of anthropology. In 1934, he was invited by a number of universities in Europe to deliver lectures, and for this purpose visited Oxford, Paris, Rome, Florence, Vienna, Berlin, Königsberg, Halle, Bonn and Cologne. In July of that year, he was present at the International Anthropological Congress in London when he read a paper on the 
agricultural basis of religion in southern India, and directed attention to the somewhat inadequate provision made on this occasion for the consideration of the results of Indian ethnographical research. In January last, he presided for the last time over the Anthropological Section of the Indian Science Congress Association, held at Secunderabad, when he dealt in his presidential address with his recent work in the Coorg State.

Ananthakrishna Iyer's publications are too numerous to mention here. During a period of forty years he was connected with most of the learned societies dealing with anthropology in Europe and America. He was a foundation fellow of the Indian Academy of Science, Bangalore, and of the National Institute of Science, Calcutta. In 1935 he was made officier de l'Académie Française and honorary doctor of medicine and surgery of Breslau. In the same year he was promoted from Rao Bahadur (192I) to Diwan Bahadur, by the Government of India. By his death, India loses an indefatigable and learned worker in the field of ethnographic study who cannot readily be replaced. His many friends both in that country and in England will regret the passing of an attractive and vigorous personality.

R. E. Enthoven.

\section{Dr. T. G. Macaulay Hine, O.B.E.}

Dr. T. G. M. Hine, who died on April 25 at the age of sixty-six years, was the son of the late Mr. George Hine, an architect in large practice. From close association with his father, Hine acquired an excellent knowledge of business, and in his youth spent a year in Germany at the practical study of engineering. Educated at Charterhouse, King's College, Cambridge, and St. Bartholomew's Hospital, Hine, after qualify. ing and acting as house physician, settled down to the study of bacteriology and investigated the fermentative character of organisms of the diphtheria group.

Hine's chief chance, however, came when during the first winter of the Great War cerebrospinal fever broke out among the mass of troops then in training and, as recruits are specially susceptible to the disease, a very serious outbreak was threatened. The disease was known to be due to the meningococcus and to be conveyed by droplet infection through a chain of healthy carriers who harbour the organism temporarily in their nasopharynx. The D.G. of the Army Medical Service, the late Sir Alfred Keogh, was advised as to the measures taken by Sir William Horrocks assisted by the late Dr. Richard Reece and Dr. Mervyn Gordon, whose services were supplied by the Medical Research Committee. A central laboratory was set up at Millbank (headquarters of the R.A.M.C.) with a travelling laboratory attached and Dr. Hine was put in charge. In order to check the disease, contacts were swabbed, carriers segregated, and intensive research undertaken in which Martin Flack, W. J. Tulloch, J. A. Glover, and A. G. Bell all made valuable contributions.

As each salient point came to notice it was applied by Dr. Hine. Thus (1) the first requirement was a suitable medium that could be supplied in bulk for identifying carriers of the meningococcus. When this was arrived at, Dr. Hine manufactured it on a large scale and kept more than fifty laboratories dealing with troops supplied. (2) It was soon found that the only safe way to identify the meningococcus was by serological means, and that four different types of it were operating, of which two were responsible for 80 per cent of the cases. The largescale production of menotypical agglutinating serums for identifying these strains of the meningococcus, and homologous suspensions for checking the sera, was undertaken by Dr. Hine, who later on was succeeded in this work by Commander A. G. Bell. (3) When trial was made of monotypical therapeutic serum standardized by its antiendotoxic capacity, Dr. Hine undertook its distribution and the assessment of results. This serum was particularly successful in patients infected by Type $\mathrm{I}$, the main epidemic strain of the meningococcus, in which the mortality had previously been highest, but less successful in cases infected by the other types. (4) When it was found by experiments on carriers at the central laboratory that the meningococcus can be destroyed in their nasopharynx by causing them to inhale through the nose the air of a room densely charged with a spray of droplets of I : 50 zinc sul. phate, Hine's previous engineering experience enabled him to design a jet that was more efficient than the one previously in use.

Although the disinfection of carriers by this means was only temporary, it proved valuable for dealing with instances of mass infection, and when applied the last thing at night before going to bed, appeared to stop the incidence of the disease in some outbreaks: the disease ceasing while the spray treatment was in use and beginning again when it was stopped. The Navy adopted Hine's jet for installation in the Fleet, where it was operated by compressed air instead of by steam as in the Army.

For his services during the War, Dr. Hine received the O.B.E. and was made an honorary major in the Army. After the War, he gave assistance for a time to the administrative staff of the Medical Research Council and then retired to his house near Slapton in South Devon. Dr. Hine was a popular figure in lay as well as medical circles, and was a past Master of the Fruiterers' Company.

We regret to announce the following deaths :

Prof. R. H. Fernald, director of the Department of Mechanical Engineering and dean of the Towne Scientific School of the University of Pennsylvania, known for his work on fuel technology, on April 24, aged sixty-six years.

Prof. A. R. Ling, emeritus professor of malting and brewirg and of the biochemistry of fermentation in the University of Birmingham, on May 14, aged seventy-six years.

Prof. L. W. McCay, emeritus professor of chemistry in Princeton University, known for his work on the chemistry of arsenic, on April 13, aged seventy-nine years. 